\title{
O IMPÉRIO É QUE ERA A REPÚBLICA: A MONARQUIA REPUBLICANA DE JOAQUIM NABUCO
}

Christian Edward Cyril Lynch

Eu era monarquista porque a lógica me dizia que não se devia absolutamente aproveitar para nenhuma fundação nacional o ressentimento do escravismo; por prever que a Monarquia Parlamentar só podia ter como sucessora revolucionária a Ditadura Militar, quando sua legítima sucessora evolutiva era a Democracia Civil; por pensar que a República no Brasil seria a pseudorrepública que é em toda a América Latina. Eu dizia que a República não poderia funcionar como governo livre; e que, desde o dia em que ela fosse proclamada, desapareceria a confiança, que levamos tantos anos a adquirir sob a Monarquia, de que a nossa liberdade dentro da lei era intangível.

(NABUCO, 1999, P. 60)

O pensamento de Joaquim Nabuco pode ser compreendido grosso modo como dividido em três períodos: o abolicionista (década de 1880); o monarquista (década de 1890); e o panamericanista (década de 1900). A fase mais festejada é, sem dúvida, a primeira. Há vinte anos celebra-se o Nabuco de Discursos parlamentares, $O$ abolicionismo, a Campanha 
abolicionista do Recife e $O$ erro do imperador como um verdadeiro herói, tendo a academia o elevado à justa condição de precursor do pensamento social brasileiro. Nessa celebração, Nabuco costuma ser apresentado como um social-democrata avant la lettre cuja visão arguta da sociedade brasileira lhe teria permitido enxergar, num meio adverso e conservador, os males decorrentes de nossa má-formação, bem como mobilizar a sociedade civil da época para forjar um país mais justo, mais solidário, mais cidadão. Em contraposição a esse Nabuco da primeira fase, aquele da segunda costuma ser lido em chave diametralmente oposta. Tendo abandonado sua preocupação social-democrata, depois de 1889 Nabuco teria chafurdado num lamentável conservadorismo, opondo-se à propaganda republicana e afogando as mágoas da queda da monarquia nos braços do catolicismo militante. Ou seja, virara um reacionário. A mesma má-vontade se transmite à qualificação de sua produção intelec278 tual, como a Resposta às mensagens de Recife e de Nazaré, Por que continuo a ser monarquista, Balmaceda, A intervenção estrangeira na revolta de 1893, O dever dos monarquistas e, finalmente, $U m$ estadista do império. A despeito dos elogios ao mérito artístico e historiográfico dessa última, ou a algumas das observações de Balmaceda, a impressão geralmente publicada é a de que, do ponto de vista político, tais obras não passariam de propaganda sem valor, expressão de saudosismo monarquista ou despeito aristocrático. Resultado: celebra-se o Nabuco abolicionista, porque "progressista" e "moderno", e detrata-se o monarquista, porque "atrasado" e "conservador".

O que teria acontecido com Nabuco, tornado a sombra de si mesmo? Embora alguns tenham se limitado a assinalar a mudança ${ }^{1}$, houve quem arriscasse explicações. Para um

\footnotetext{
1 Esta é a posição de Ricardo Salles, que traça uma das mais lúcidas interpretações sobre o processo político de passagem da Monarquia à República (Salles, 1996). Em seu artigo, porém, refere-se ao fato de que Nabuco teria abandonado a ação cidadã - começada pelo abolicionismo - para abraçar uma posição conservadora e elitista
} 
de seus biógrafos, Luís Viana Filho, Nabuco sofria de um romantismo incurável, que o levava a um excesso de imaginação idealista. Essa, na verdade, era a imagem que o pragmático conservadorismo da Primeira República tinha do liberalismo progressista em geral e de Nabuco em particular: "tímido", "ingênuo", "vacilante", "sentimental", "iludido", "idealista”, são alguns dos epítetos que lhe reservam o pouco generoso biógrafo. O monarquismo de Nabuco era uma "ilusão", na qual "simultaneamente residia a fraqueza do político, que não via claro, e a força do idealista, que precisava nutrir-se de todas as quimeras" (Viana Filho, 1952, p. 185). Para o crítico literário Antonio Candido, por sua vez, o conservadorismo de Nabuco tinha outra origem: ele residia no seu "aristocratismo crônico". A explicação passava agora pelo crivo marxista. Embora tivesse conseguido "sair do círculo de interesses de sua classe" para tornar-se um "radical" na década de 1880, depois de 15 de Novembro teriam agido sobre Nabuco "os atavismos de classe", em razão dos quais "ele passou ao liberalismo atenuador de Um estadista do império, elaborado longe do povo, em diálogo tácito com as sombras de um passado que interferiu em suas ideias". Para piorar, ao tornar-se pan-americanista, Nabuco não teria percebido "que o imperialismo norte-americano era tão grave no plano externo quanto fora a escravidão no plano interno". Nessa leitura, portanto, Nabuco não se tornou conservador porque sempre o fora, em razão de seu vínculo com a classe aristocrática; sua participação no abolicionismo é que representara um desvio. Conclusão: Nabuco havia sido um "radical temporário", voltando depois à sua posição "conservadora" (Candido, 2004, p. 200). Na década de 1980, o primeiro grande estudioso de seu pensamento político aventou uma hipótese mais elabo-

(Salles, 2000). Em sua obra especificamente sobre Nabuco, porém, Salles privilegia mais a dimensão sócio-historiográfica do que a política (Salles, 2002). 
rada: a de que Nabuco teria "perdido o bonde da história". Segundo Marco Aurélio Nogueira, "alinhando-se incondicionalmente com o Império, Nabuco deixava de revelar que as mudanças em curso no país - embora sem força suficiente para romper com o caráter conservador do processo global - exigiam um reordenamento político institucional que ultrapassava a monarquia" (Nogueira, 1984, p. 159)².

Mais recentemente, a interpretação "classista" de Antonio Candido foi retomada e atualizada por Angela Alonso. Nabuco surge aí como um aristocrata, ligado por razões contingentes ao "reformismo" do final do Império (Alonso, 2002). O elemento que explica a dedicação do deputado liberal à sorte dos escravos - e que faltava no esquema interpretativo de Candido - é a sua "vaidade":

Quincas consolidava sua combinação duradoura de melancolia e narcisismo. Era enamorado de si mesmo, mas vivia mal a solidão. Precisava confirmar suas qualidades por meio do afago e da recepção calorosa de um público. Esse sentimento o encaminhou para a conquista do apreço alheio, das mulheres, como dos homens, não só dos amigos, como dos adversários, dos íntimos e das multidões (Alonso, 2007, p. 37).

Em outras palavras, Nabuco só se interessa pelos escravos por um capricho estético, pois que vê neles um instrumento de sua vanglória - numa palavra, de sua vontade de aparecer. Nesse ponto, Alonso retoma a interpretação de Candido: a abolição da escravatura, a queda da Monarquia e o advento da República teriam despertado em Nabuco "seu tradicionalismo de origem" (Alonso, 2007, p. 233).

2 O posicionamento de Nogueira a esse respeito se matizou consideravelmente em seus últimos trabalhos, notadamente no artigo de 2000 e na introdução à segunda edição de sua obra de 1984, datada de 2010, de cuja perspectiva se aproxima o presente artigo. 
Por isso mesmo, sua obra da década de 1890 teria passado a refletir esse caráter de propaganda aristocrática contra os "arrivistas", os "democratas" que haviam tomado o poder (Alonso, 2009a, 2009b). Nabuco se tornara um "ressentido", um "despeitado", qualidades negativas que se refletiram na obra escrita durante a década, que não passariam de miserável propaganda monarquista.

Parece-me que diversos equívocos predominam nesses enfoques, entre os quais a falta de familiaridade com a cultura liberal Oitocentista; um intencionalismo mal-entendido, descontextualizado ou anacrônico; a persistência de métodos reducionistas que aprisionam seu pensamento nas malhas do psicologismo ou dos supostos vínculos de classe. Não há aqui espaço para discuti-los como convém. Basta por ora salientar que a maioria deles decorre de uma interpretação de corte evolucionista e positivista da passagem da Monarquia à República, que nesses enfoques serve de pano de fundo ao exame do "segundo Nabuco". Depois de instaurado o novo regime, ela encontrou o seu primeiro modelo acabado na História constitucional da república dos Estados Unidos do Brasil, de Felisbelo Freire - na época o principal defensor intelectual da ditadura florianista contra os ataques a ela dirigidos por Rui Barbosa e pelo próprio Joaquim Nabuco. Essa interpretação - que pode ser inscrita na tradição "luzia" em contraposição àquela cuja denúncia anda na moda, a "saquarema" (Mello, 2001) - postula, em suas linhas gerais, que o Império era um bloco de instituições surgidas de circunstâncias contingentes e só subsistiu enquanto cumpria papéis compatíveis com o baixo desenvolvimento socioeconômico da sociedade brasileira, inclusive o escravismo. Como tal, a Monarquia estava fadada a ser substituída por uma moldura institucional mais moderna, fatalmente republicana. A Monarquia unitária é apresentada como uma continuação disfarçada do período colonial; um desvio de rota transitoriamente útil que se tornara, 
porém, ao cabo de certo tempo, uma pedra no progresso nacional, natural e felizmente superada pela República federativa, verdadeiro advento da modernidade no Brasil. Tanto assim que, a respeito dos acontecimentos de 15 de Novembro, evita-se falar em golpe militar, preferindo-se a eufemística expressão "proclamação da República" - como se tratasse de uma mudança tão natural ou fatal quanto a transformação da lagarta em borboleta ${ }^{3}$.

Atualizada e adaptada por jacobinos, perrepistas e castilhistas, essa interpretação foi depois abraçada por parte do mainstream acadêmico marxista, que substituiu o evolucionismo/positivismo pelo materialismo histórico sem alteração substantiva dos traços assinalados: caráter acidental da Monarquia no Brasil; relação indissociável da Monarquia com a centralização política, a ascendência do Poder Moderador e a vitaliciedade do Senado; superação do Império como telos, em virtude de um imperativo modernizador. 282 Essa interpretação luzia da passagem da Monarquia à República tem dificultado sobremaneira, quando não impedido, uma avaliação serena da obra nabuqueana no período, condenada pelo evolucionismo/positivismo por ser liberal, e pelo marxismo, por ser conservadora. Ela confere ao advento desse regime um caráter falso de necessidade histórica, na medida em que confunde dois objetos distintos de análise: a oligarquização ou democratização como processo histórico, isto é, conjunto de causas e consequências de um processo de mudança social, que teria um "sentido", e a instauração da República enquanto modalidade de mudança, resultante de uma dinâmica particular e acidental de ação

\footnotetext{
3 Isso sem falar na eventual ilusão de que o jacobinismo pudesse ter representado uma alternativa democrática ao desfecho oligárquico, quando se aproximava mais de um movimento de índole cesarista, sectário e autoritário - uma "direita revolucionária" antiliberal, similar ao boulangismo protofascista que, na França, ameaçava destruir a Terceira República (Sternhell, 1997).
} 
coletiva $^{4}$. Na verdade, nada há que indique que o processo de mudança social em curso exigisse a instauração da República, ou seja, que ele não pudesse ter-se operado sob o signo do Império reformado, federalizado, na forma de uma "república velha coroada". É de bom alvitre lembrar que, como todas as monarquias do período, inclusive a britânica, o Império reformou o seu modelo político por pelo menos três vezes $(1834,1837,1881)$, e estava a ponto de operar a quarta, sob o Gabinete Ouro Preto, quando foi derrubado. A história é pródiga em demonstrar que a Monarquia pode se combinar indiferentemente com a democracia ou o absolutismo; o sufrágio censitário ou universal; a centralização ou o federalismo; o governo pessoal ou o parlamentarismo; o contencioso administrativo ou judiciarismo etc. Se o problema é a incompatibilidade entre o continente americano e a Monarquia, o Canadá está aí para indicar o oposto; ademais, deve-se recordar que a forma monárquica de governo havia sido a primeira opção de importantes setores de diversos países da América Ibérica, inviabilizada mais por motivos contingentes que por qualquer outro (Lynch, 2008).

No espaço disponível do presente artigo gostaria de sugerir uma interpretação alternativa do pensamento de Nabuco naquele período, formulada a partir de seus próprios termos. Sua virtude está menos na originalidade do que na ênfase e na sistematização de aspectos já sublinhados, embora isoladamente, por estudiosos como Evaldo Cabral de Mello, José Almino de Alencar, Maria Alice de Carvalho, Maria Fernanda Lombardi, e Marco Aurélio Nogueira ${ }^{5}$.

\footnotetext{
4 Trata-se visivelmente de um cacoete análogo àquele da historiografia marxista a respeito da Revolução Francesa, denunciado por François Furet (1989, p. 36).

5 Refiro-me expressamente à alusão de Marco Aurélio Nogueira à "tensão dialética” que caracteriza a relação de Nabuco entre o ideal e o real (Nogueira, 2000); à afirmação de José Almino de Alencar ao pensamento de Nabuco nas décadas de 1880 e 1890 numa chave mais de continuidade do que de ruptura (Alencar, 2008); à leitura de Maria Alice Rezende de Carvalho do monarquismo de Nabuco como um republicanismo pelo alto (Carvalho, 2000); à observação, por Maria Fernanda
} 
Na base dessa interpretação, está a tese de que o segundo Nabuco se acha movido pela mesma preocupação do primeiro, diante, todavia, de uma conjuntura diferente, de substituição do regime de governo que tornara possível o abolicionismo, levando-o a perceber a instabilidade do terreno sobre o qual julgara possível instaurar a democracia no Brasil. A escalada de eventos como o recrudescimento da propaganda republicana pela adesão dos fazendeiros escravocratas; a ruptura institucional com o Estado de direito operada pelo golpe militar; a queda do padrão de vida pública acelerada pelo Encilhamento e o advento da ditadura florianista, sustentada pela violência do jacobinismo urbano; todos esses foram acontecimentos que marcaram e tornaram mais complexa a elaboração teórica de Nabuco, obrigando-o a se debruçar sobre as condições de possibilidade de uma sociedade republicana e liberal no Brasil. Enxergando suas obras da década de 1890 à luz de seus con284 ceitos-chave - como o de "idealismo prático" e o de "República" -, conclui-se que Nabuco permaneceu monarquista por julgar que o advento do regime republicano, nas condições propostas, viria a prejudicar e não a favorecer o advento de uma sociedade autenticamente republicana, liberal e democrática entre nós. Por outro lado, considerações de ordem estritamente prática levavam-no a ver, na Monarquia preexistente, um instrumento que permitiria promover mais efetivamente o civismo, o liberalismo e a democracia, capaz de preparar a sociedade brasileira para uma República que fosse além do mero rótulo, ou seja, sem desnível entre forma e conteúdo; entre o país legal e o país real. Por

Lombardi, do maior comprometimento de Nabuco com os valores republicanos do que os próprios republicanos, como Silva Jardim (Fernandes, 2007); e, por fim, a duas observações de Evaldo Cabral, a primeira concernente às afinidades de Nabuco com o discurso político saquarema (Mello, 1997), e a segunda, à relatividade de seu suposto elitismo no contexto de um regime republicano que era tão ou mais elitista (Mello, 2000). 
fim, reforçando a hipótese do monarquismo instrumental de Nabuco, chamarei a atenção para o modo por que ele pensou uma eventual reorganização do novo regime republicano a partir da experiência imperial, de modo a minimizar a solução de continuidade operada, a seu ver, quando do golpe militar de 1889 .

\section{Entre o ideal e o real: o "idealismo prático" de Nabuco}

Ao exemplo de outros grandes liberais do século XIX, como Madame de Stäel e Benjamin Constant, o pensamento de Joaquim Nabuco é atravessado pela necessidade de orientar-se a partir de padrões ideais, marcados por forte apelo estético e moral, mas também pelo imperativo de compreender a realidade por intermédio de agudo um faro sociológico. Desde a juventude, acompanhou-o a tendência a esse idealismo estetizante que associava o verdadeiro ao bom, belo, moral e eterno, e remetia o falso, por sua vez, à maldade, à fealdade, à degeneração, ao efêmero. Para ele, cada ser humano poderia ser resumido ao "raio estético" existente no interior do seu pensamento, sendo a política apenas "uma refração daquele filete luminoso que todos temos no espírito" (Nabuco, 1949b, p. 49). Entregue apenas às próprias forças, sem nenhum artifício que a resgatasse, a vida ordinária tenderia inevitavelmente à decadência, à corrupção, à velhice. A vida terrena ou mundana, ordinária, precária e fragmentária, só fazia sentido caso orientada por aquele ideal, que poderia conferir-lhe a unidade, o sentido e a orientação de que ela carecia (Nabuco, 1901, p. 195).

O principal binômio que reflete aquela dicotomia é a distinção entre a "grande política" ou "política com P grande" e a "pequena política”, ou "política com P pequeno". A primeira é "a política que é História”, "onde a ação do drama contemporâneo" seria "universal”, "do século”, "da civilização", "intelectual”, "cosmopolita”. A segunda, por seu turno, era a "política pelos profissionais", "que é a local, a 
do país, a dos partidos”, e, como tal, é "puramente doméstica". Isso significa que a política brasileira só lhe interessava na medida em que envolvesse os fatos históricos da nacionalidade, refletindo desse modo a "grande política" (Nabuco, 1949b, pp. 42-43). Projetado a partir de uma estética cujo tom é conferido pela arte e pela história, esse idealismo se projeta em toda a sua visão do mundo e o acompanha num crescendo conforme amadurece e envelhece. Com efeito, conforme vive, sua preocupação sucessivamente se transporta, como que numa escalada ou numa ascensão, da política ordinária à causa social da Abolição, dessa ao problema do Estado de direito na América Latina, para por fim chegar ao plano da História e dos destinos do país no cenário internacional. Sua tão controversa "conversão" católica deve ser vista como consequência do movimento ascendente daquele idealismo estético, no plano do foro íntimo, acelerado pelas frustrações políticas. Para Nabuco, por simbolizar a 286 unidade, a bondade, a moralidade, a eternidade que devem preponderam sobre a fragmentação, o egoísmo, o materialismo e a efemeridade da vida terrena, Deus naturalmente figuraria em sua arquitetura intelectual e moral como a abóboda do edifício: "Toda ideia é espelho de Deus, para quem a puder polir até o infinito" (Nabuco, 1937, p. 17). Civilização e barbárie, liberalismo e tirania, Monarquia e República, parlamentarismo e presidencialismo, Europa e América, vida ativa e vida contemplativa, são outros tantos binômios que refletem o seu idealismo político. "A felicidade é a admiração do belo em companhia daqueles com quem estamos em harmonia" (Nabuco, 1937, p. 96). Nesse sentido, é evidente a afinidade de Nabuco com a filosofia platônica, com a qual, de fato, ele começou a vida intelectual e a concluiu, dedicando-lhe quatro conferências ao sair da faculdade, e relendo-a no leito de morte, quarenta anos depois: "Que sol resplandecente Platão me está aparecendo!”, exclamava Nabuco semanas antes de morrer. "Não sei se é tarde aos 60 
anos para entrar para a Academia, mas é o mais conveniente preparo para a eternidade" (Nabuco, 2005, pp. 470, 473).

No entanto, esse "platonismo" ou idealismo de Nabuco tinha por contrapartida, paradoxal apenas na aparência, o imperativo de interpelar a realidade o mais objetivamente possível. Nesse sentido, Nabuco também seguia as intuições dos liberais franceses, que desde Constant reconheciam a necessidade de adotar "princípios intermediários" que filtrassem a verdade abstrata e universal contida nos princípios absolutos e os encadeassem e concretizassem, conforme as circunstâncias de tempo e de lugar. "A regra de conduta, em moral política, não é querer realizar um ideal absoluto, mas tê-lo diante de nós como um ponto fixo, de modo que caminhemos sempre para ele" (Nabuco, 1901, p. 610). Assim, todo o verdadeiro estadista deveria se orientar na vida pública por um critério a que Nabuco denominava "idealismo prático": esse último se distanciava tanto do idealismo puro, que levava ao radicalismo teórico e afastava o ator do objetivo, quanto do pragmatismo, em que o ator agia em função de puros interesses práticos na busca pelo poder. A fundamental qualidade do político era "adaptar os meios aos fins e não deixar periclitar o interesse social maior por causa de uma doutrina ou de uma aspiração" (Nabuco, 1949b, p. 203). Esse ponto de vista - que, entre Platão e Maquiavel, pode ser chamado "aristotélico" - postulava a esterilidade da política puramente ideal na medida em que o desconhecimento do real a privava da possibilidade de efetivação: "É uma pura arte de construção no vácuo. A base são teses, e não fatos; o material, ideias, e não homens; a situação, o mundo, e não o país; os habitantes, as gerações futuras, e não as atuais" (Nabuco, 1949, p. 17). Nabuco exigia do ator político orientado pelo ideal uma proficiência quase científica na apreciação das realidades, de tal sorte que pudesse aproximar o ideal o tanto quanto possível do real. Daí que, noutro pensamento, exprima essa 
hierarquia invocando os filósofos que encarnariam aquelas características: "A terra gira em torno do sol; Aristóteles em torno de Platão” (Nabuco, 1937, p. 62). Era o seu jeito de afirmar que era o ideal que orientava o conhecimento do real.

Mas quais eram os ideais políticos de Nabuco? Aqui é preciso compreendê-los no interior da cultura política liberal Oitocentista, relacionando-os à filosofia da história como progresso: esclarecimento, capacidade, moralidade, civismo, tolerância, abertura à democracia. E era na Inglaterra que esses ideais pareciam mais bem se materializar: dona de um império que cobria a quarta parte do mundo, terra da liberdade civil, governada por uma aristocracia ilustrada e patriótica, ninguém duvidava de sua posição na vanguarda do processo civilizatório. Além disso, Tocqueville e Mill haviam ensinado que havia um movimento histórico e social irrefreável de democratização, que levava, no plano social, à desaristocratização das sociedades e, no plano polí288 tico, ao sufrágio universal. O papel do liberal autêntico seria o de encaminhar a democratização sem prejuízo da qualidade da vida pública, ou seja, dos valores cívicos e liberais da aristocracia declinante. Ora, era também a Inglaterra o país onde esse ideal whig de democratização dentro do liberalismo se realizava de maneira ordeira e pacífica (Mitchell, 2005, pp. 113-114, 177). Por outro lado, os Estados Unidos ainda pareciam a muitos um rebento da linhagem inglesa, que se destacava antes pelo seu progresso material do que moral (Nabuco, 1949b, p. 175). Quanto à França, era a única república entre as potências europeias, e a ninguém parecia modelo de coisa alguma com seu modelo parlamentar bastardo, sua pulverização partidária e seus governos cronicamente instáveis, atacados pelos jacobinismos de direita e de esquerda. Era, pois, natural que a monarquia parlamentar britânica servisse de referência a todos os liberais que anelavam, para além do Mancha, combinar o progresso na ordem, a liberdade com a autoridade. 
Se tais eram os ideais liberais de Nabuco, qual a realidade com que eles deveriam ser contrapostos, para fins de elaboração da estratégia política a mais adequada aos atores - sempre em conformidade com o idealismo prático por ele preconizado? Essa realidade era a da sociedade latino-americana, tão diferente da europeia em geral e, em particular, da britânica. De fato, os países da região eram republicanos apenas no nome, oscilando na realidade entre a anarquia da guerra civil e a tirania do governo pessoal: "Em toda a América do Sul, há neste momento, como tem havido sempre, uma porção de revoluções à espera somente de um pretexto para rebentar" (Nabuco, 1949, p. 124).

\section{O Estado de direito possível na América do Sul: liberalismo aristocrático versus caudilhismo autoritário}

A pergunta que serve de ponto de partida para a reflexão de Nabuco no período é, portanto, a seguinte: seria possível organizar àquela altura, na América Latina, um Estado de direito (entendendo-se por esta expressão um governo constitucional e representativo efetivo e não apenas nomi$n a l)$ ? Montesquieu e Tocqueville haviam ensinado que a liberdade só medrava onde houvesse, no âmbito da própria sociedade organizada, obstáculos à expansão indefinida do poder (Nabuco, 1949, p. 138). Ocorre que, recém-saídas da colonização, as sociedades civis latino-americanas ainda eram desestruturadas, politicamente invertebradas, não dispondo de qualquer mecanismo que, à luz daqueles autores, pudesse impedir o livre desenvolvimento do despotismo. Dado o caráter naturalmente anárquico da cultura política subcontinental, o imperativo modernizador exigia a imediata construção da ordem nacional, não se podendo aguardar que o tempo se incumbisse de estruturá-la naturalmente. Tratava-se, assim, de uma razão de Estado a ser executada por meios extraordinários e artificiais, apelando-se a uma institucionalidade capaz de impor a paz de cima para baixo 
e de exercer transitoriamente determinadas funções que, segundo o figurino clássico do liberalismo, deveriam ser exercidas pela sociedade, mas de que, na região, ela ainda não era capaz de se desincumbir. Essa institucionalidade precisaria adquirir, ao menos nos primeiros tempos, um cunho aberta ou veladamente monárquico, para conseguir cimentar as fidelidades, dar liga aos fragmentos de sociabilidade existentes e combater os focos de desagregação. Servindo de contraforte às tendências anárquicas do meio, ela serviria de plataforma para estabelecer o Estado de direito e democratizar-se num futuro mais remoto. Para os realistas liberais sul-americanos, como Caravelas, Portales, Uruguai e Alberdi, a tutela monárquica, sob a forma de república ou não, serviria de estufa que permitisse aclimatar a liberdade num ambiente que lhe era estranho: individualista, apaixonado, incoeso, carente de ordem. Ainda que de forma discreta, inconfessa, eles exprimiam a ideia, repetida 290 em meados do século por Mill e Tocqueville, de que toda comunidade política inorgânica carecia em seus primeiros tempos de um "despotismo benévolo" - até que a sociedade conseguisse caminhar com suas próprias pernas ${ }^{6}$.

Mas de onde viria o impulso para instaurar aquela ordem, sendo a sociedade bárbara e desarticulada? Naquela etapa ainda embrionária do desenvolvimento dos países da região, era inevitável que a instauração de um Estado comprometido com os valores civilizatórios dependesse pri-

\footnotetext{
6 A respeito da América do Sul, cujas "novas nações" se agitavam havia "um quarto de século, em meio a revoluções sempre renascentes", Tocqueville escrevera: "Quando o considero (o povo desses países) nesse estado alternante de misérias e crimes, sou tentado a crer que para ele o despotismo seria um bem" (Tocqueville, 2001, p. 263). Duas décadas depois, Stuart Mill escreveria que "um povo que se encontra em estado de independência selvagem [...] é praticamente incapaz de realizar qualquer progresso em civilização até ter aprendido a obedecer. Por conseguinte, a virtude indispensável em um governo que se estabeleça sobre povo dessa espécie é fazer-se obedecido. Para permitir que o consiga, a constituição do governo deve ser aproximadamente ou mesmo completamente despótica" (Mill, 1983, p. 28).
} 
mariamente da iniciativa e êxito de elites esclarecidas, cujo liberalismo e cujo patriotismo as motivassem a limitar voluntariamente o próprio poder governamental nos limites de um governo constitucional e representativo. $\mathrm{O}$ advento da civilização dependia de uma sociabilidade cosmopolita que, num meio social decaído a mais de um título, só poderia ser encontrada numa diminuta parcela da população correspondente à sua aristocracia. Eis por que ela deveria se colocar à testa das iniciativas governamentais para promover a civilização do país - isto é, à defesa da ordem liberal, se opondo artificialmente às naturais tendências bárbaras, isto é, autoritárias, do meio social, mediante o seu "espírito de transação" (Nabuco, 1949, p. 124). Esse governo de excelência se organizaria pelo governo parlamentar e se manteria pelo estabelecimento de regras de acesso aos cargos públicos destinadas a selecionar pessoas educadas, ou seja, de perfil compatível com os valores liberais e republicanos para o exercício das funções governativas, evitando a ascensão de gente estranha àquela sociabilidade, contaminada pelo atomismo do meio. Naquela etapa do desenvolvimento do subcontinente, esse domínio oligárquico da "aristocracia" social na esfera política deveria ser reputado legítimo enquanto estivesse comprometido com a prática e o enraizamento do Estado de direito no ambiente que lhe era adverso. Como um whig, Nabuco esperava que, pelo respeito reiterado dos frágeis precedentes e práticas liberais, com o tempo os valores da civilização se sedimentassem na forma de uma cultura política (Mitchell, 2005, pp. 113-114, 177). Para tanto, as elites políticas não poderiam perder o tino sociológico, o espírito prático, positivo, que evitasse o utopismo e, com ele, o radicalismo que punha tudo a perder; deveriam estar embebidas do seu "idealismo prático".

Nesse ponto, tem se objetado ao que parece um "aristocratismo político", uma aversão do fino Nabuco à plebeia democracia. Para Nabuco - como, depois dele, para 
Ostrogorski, Michels, Pareto e Weber -, todos os tipos de governo eram oligárquicos, no sentido de que era sempre uma minoria que governava; nesse sentido, a democracia era o regime em que a oligarquia governava com o assentimento da maioria (Nabuco, 2005, p. 221). Além disso, Nabuco pensava que, dado o atraso das sociedades da região, não havia qualquer possibilidade em curto prazo de estabelecimento da democracia na América do Sul. Ela mesma só existia em marcha estável nos Estados Unidos e na Inglaterra, sofrendo abalos na França, e apenas engatinhando na Itália. Daí que o seu liberalismo aristocrático não se opunha ao democratismo, mas a outra forma de oligarquia que lhe parecia muito pior de oligarquia - a tirania demagógica. A "democracia” não passava aí de pretexto risível para que os candidatos a tiranos promovessem seus pronunciamentos e instalassem regimes personalistas, autoritários, oligárquicos, antirrepublicanos. Forma políti292 ca típica de governo da região, a principal característica da tirania demagógica residia na defesa da autoridade pessoal do tirano a qualquer custo. Para permanecer no poder, o déspota sacrificava, abertamente ou por sofismas, todos os preceitos do Estado de direito, fraudando eleições, censurando a imprensa, perseguindo e executando adversários - sempre, em nome do povo (Nabuco, 1949, p. 77). Por essa razão, a violenta rotação do pessoal governante pela revolução nunca passava, a seu ver, de mera substituição de oligarquias para pior, na medida em que o pessoal mais tradicional, ilustrado e independente era substituído por outro, arrivista e dependente do ditador e, portanto, predisposto a chancelar toda e qualquer violência para segurar-se no poder. $\mathrm{O}$ resultado era que, como o Estado de direito nunca dispunha de tempo, hábitos e práticas para se sedimentar, meio às perseguições das minorias e reiteradas violações da ordem constitucional, a cultura política liberal nunca conseguia se enraizar, ficando o sonho da democracia cada vez mais distante. 
Assim, o aristocratismo de Nabuco não se opunha à democracia, mas à oligarquia e à tirania. Pensando, como Tocqueville e Mill, a partir de um esquema em três etapas de desenvolvimento político - primeiro a ordem, depois o liberalismo e, por fim, a democracia -, Nabuco partia da premissa de que, pelo retardo de suas desestruturadas sociedades, ainda não havia em nenhum país do continente condição de implantação de regime democrático. Oscilando entre a anarquia da guerra civil e a tirania personalista de um general, boa parte das nações sul-americanas sequer conseguia cumprir a primeira etapa, que era a de garantir a ordem pública pelo monopólio estatal da coerção legítima. Daí que, para o autor de Balmaceda, o dilema sul-americano ainda não se punha em termos de regime democrático ou não democrático, mas entre barbárie e civilização; governo oligárquico ou aristocrático; individualismo feroz ou sociabilidade plural; caudilhismo autoritário e liberalismo aristocrático. Enquanto oligarquias políticas, tanto a aristocracia liberal chilena como a liberal inglesa lhe pareciam governar mais no interesse do povo do que tiranos arbitrários como Rosas na Argentina, Garcia Moreno no Equador, Francia no Paraguai, Melgarejo na Bolívia, porque a aclimatação da liberdade preparava o terreno da democracia, e a tirania, não (Nabuco, 1949, p. 80). A civilização democrática só se tornaria possível quando, concomitante à diluição da hegemonia política da aristocracia, houvesse uma irradiação do seu "espírito liberal" por sobre as camadas sociais politicamente emergentes. Ao aclimatar o sentimento da coisa pública, o governo dos melhores homens e a cultura política liberal, um governo aristocrático consolidado constituía o único caminho por que o Estado de direito poderia chegar à América Latina, até que a sociedade conseguisse se estruturar e criar condições para uma evolução democrática. Sem aristocracia governante, também não seria possível cogitar das reformas sociais indispensáveis ao progresso de 
suas nações, reformas estas que deveriam ser promovidas em consonância com figurino whig: cautelosamente, sem movimentos abruptos que pusessem em perigo a estabilidade das instituições e, com ela, a teia evolucionária liberal produzida ao longo do tempo. Porque respeitador de todos os direitos, o espírito de reforma conservador, burkeano, é recomendado por Nabuco como o verdadeiro espírito republicano (Nabuco, 1949, p. 39).

Pintado tal pano de fundo da realidade sociopolítica sul-americana, indaga-se: que modelos institucionais ou constitucionais poderiam contrapesar as insuficiências do meio social, servindo de incubadoras do Estado de direito? A Monarquia agradava ao idealismo estético de Nabuco, porque refletia a imagem de Deus governando o universo e exprimia a aspiração platônica do governo belo, justo e perfeito; o ideal de uma elevada esfera de moralidade que planasse sobre as misérias da ambição humana, ser294 vindo-lhe de corretivo e inspiração (Nabuco, 1949, p. 132; 1949b, p. 42). Do ponto de vista mais prático, ensinavam Constant, Laboulaye e Prévost-Paradol que a Monarquia parlamentar, enquanto forma de governo constitucional representativa, proporcionava uma autoridade suprapartidária na chefia do Estado, capaz de exercer um poder moderador e, como tal, de árbitro mantenedor do sistema constitucional; magistrado inacessível às ambições vulgares da pequena política, do reacionarismo ou do jacobinismo. O exemplo, mais uma vez, vinha da Inglaterra, país em que o privilégio dinástico aproveitava apenas "a tradição nacional mais antiga e mais gloriosa para neutralizar a primeira posição do Estado. A concepção monárquica ficava sendo essa: a do governo em que o posto mais elevado da hierarquia fica fora da competição" (Nabuco, 1949b, p. 131). A Monarquia tinha, portanto, uma utilidade dupla: como instituição moderna, servia de fiadora do Estado de direito; enquanto tradição, ela simbolizava o uno no plural, o eter- 
no sobre o efêmero, o justo sobre o parcial, a coisa pública sobre o interesse particular.

Todavia, ao exemplo daqueles autores, apesar de predisposto idealmente à Monarquia, Nabuco não faria questão de nenhum regime do governo, desde que garantisse a liberdade; como "idealista prático", ele seria o primeiro a defender a necessidade de considerar as circunstâncias e o momento, opondo-se ao "maior erro que se pode cometer em política - o de copiar, de sociedades diferentes, instituições que cresceram" (Nabuco, 1949b, p. 130). A defesa da Monarquia como forma de governo adequada ao Brasil só poderia ser efetuada, assim, a partir de ponderações particulares à realidade desse último, entendida como formação social empírica diante da qual se punha o imperativo civilizador de construção da ordem liberal. Ora, a experiência sul-americana demonstrava que apenas o Chile e o Brasil haviam escapado ao rodamoinho de infortúnios que atingira seus vizinhos. Ambos haviam apelado no começo de suas vidas independentes a institucionalidades substancialmente monárquicas que, bem-sucedidas, cedo evoluíram para o Estado de direito pelo parlamentarismo. Organizado como república monárquica, o Chile possuía um "caráter nacional" similar ao inglês, o que explicava o êxito de sua sociedade na organização de um Estado de direito estável, capaz de resistir à tirania de um Balmaceda. Este não era o caso do Brasil que, além dos males gerais da formação subcontinental, tivera o seu "caráter nacional" adicionalmente prejudicado pela sua gestação "na paz e na moleza da escravidão doméstica" (Nabuco, 1949, p. 138). Ela não teria mais condições que as outras sociedades da região, pois, para oferecer qualquer obstáculo ao exercício despótico do poder - muito pelo contrário, estaria mais predisposta a ele. Muito bem: se, com uma sociedade mais predisposta que as demais ao despotismo, contra todas as expectativas, o Brasil desfrutava havia meio século de um governo parlamentar estável, 
semelhante ao do Chile, a Nabuco pareceu razoável atribuir a causa daquela excepcionalidade à outra - a de ser o único país na região organizado monarquicamente.

Com efeito, pareceu a Nabuco que, carecendo, como os demais países do continente, de um desenho institucional capaz de conferir, ao seu Estado nacional, a consistência que ele ainda não podia extrair de sua invertebrada sociedade, havia sido a Monarquia que permitira a construção do Estado de direito no Brasil. Por um lado, ela conferia ao país a autoridade autônoma de que uma sociedade amorfa carecia para gozar de uma ordem nacional; por outro, por conta de seu caráter excepcional na América, ela se via de antemão tolhida em suas derivas autoritárias, sendo obrigada a se mostrar mais liberal do que todos os vizinhos republicanos para legitimar-se entre eles (Nabuco, 1901, p. 60). Então, justamente por seu caráter "exótico" no continente, a Monarquia teria servido de muletas a uma sociedade

296 ainda paralítica, compensando "a incapacidade do povo de combater pelos seus direitos" e proporcionando um ambiente cívico "mais favorável ao crescimento da democracia” (Nabuco, 1901, p. 62-63). De fato, assim como servira de artifício para burlar o destino natural do país ao despotismo ou à oligarquia, estabilizando-lhe o tecido social, não era impossível que a Monarquia pudesse também servir de plataforma para acelerar as transformações sociopolíticas necessárias à consolidação à futura democratização do país - ou seja, na fabricação de uma sociedade verdadeiramente republicana. Nesse ponto, na reflexão nabuqueana da década de 1890, surge aquele que é o seu tema por excelência: o da Monarquia republicana.

\section{A Monarquia republicana contra a pseudorrepública}

Para compreender o alcance da Monarquia republicana de Nabuco, é preciso averiguar previamente os diversos sentidos do complexo conceito de República por ele mobili- 
zado, que pode, dependendo do contexto, adquirir quatro sentidos diferentes, embora assemelhados. O primeiro deles remete à tradição clássica, designando, por República, qualquer comunidade voltada para o bem comum, pautada pela virtude cívica, pelos costumes austeros e pelo culto da lei, e possui por conceito assimétrico aquele de "coisa privada”, associada à corrupção, ao egoísmo e à relaxação. O segundo sentido do conceito de república, ao contrário do precedente, é puramente formal: refere-se ao regime republicano de governo e tem por seu contrário aquele de Monarquia. Os dois sentidos referidos, o primeiro e o segundo, são independentes, porque um alude à substância da coisa, e o outro, à sua aparência legal, o que implica reconhecer que o sentimento de coisa pública pode, tanto quanto a corrupção, existir no regime republicano ou no monárquico. $\mathrm{O}$ terceiro sentido alude à maneira de Tocqueville a uma sociedade democrática, isto é, igualitária (também chamada "democracia pura"); ao passo que o quarto e último sentido é mais abrangente, remetendo a um ideal moderno de sociedade republicana. Ela pressuporia cumulativamente uma sociedade dotada do sentimento da coisa pública (república no sentido estrito); de um governo constitucional e representativo, garantidor dos direitos do homem (o Estado de direito, elemento liberal); e, por fim, marcada pela participação do maior número nos negócios públicos (a democracia como regime igualitário). Estes três aspectos do ideal republicano moderno emergiriam sucessivamente no decorrer de um processo social, ao cabo do qual, tendo atingido a maturidade, substantivamente republicana, a sociedade poderia dispensar qualquer espécie de tutela e adotar o regime republicano, sem receio de uma desconformidade entre a República como substância (sociedade cívica e igualitária) e como forma (regime não monárquico). Tal é o pano de fundo teórico sobre o qual Nabuco faz a defesa da Monarquia como desenho institucional mais adequado 
ao desenvolvimento e estruturação da sociedade brasileira, surtindo efeitos republicanos, liberais e democráticos - nessa ordem.

\section{A pseudorrepública}

Embora a desafortunada experiência republicana no subcontinente fosse o principal argumento de Nabuco para se opor à sua introdução entre nós, era sempre possível sustentar, ao contrário, que tendo superado o torvelinho das guerras civis na década de 1840, o Brasil já estava maduro para a República. Nabuco duvidava, contudo, da pressuposição subjacente ao raciocínio, de que a sociedade estivesse amadurecida para dispensar a tutela benéfica de um governo autônomo e ilustrado. Por isso entendia que a República só poderia ter serventia se pudesse equivaler ou superar a Monarquia enquanto governo tutelar, o que exigia em primeiro lugar averiguar o grau de idealismo, de desprendi298 mento, de sentimento republicano entre aqueles que pretendiam substituir o imperador no comando do país.

Para Nabuco, na qualidade de dissidência liberal, o Partido Republicano havia sido fundado sob o signo do idealismo. Embora houvesse quem preferisse o republicanismo sectário e antiliberal, de matriz jacobina, no grosso do partido prevalecera o republicanismo liberal e democrático de matriz anglo-saxônia - o "bom republicanismo" (Nabuco, 1949b, p. 53). No entanto, ao longo do tempo, levado pelo excesso de ambição e pragmatismo, visando ao poder pelo poder, o partido perdera de vista o povo e a República, ao jogar inescrupulosamente com os desdobramentos políticos da Abolição, com o propósito único de angariar o apoio dos fazendeiros escravocratas, e incitando o militarismo positivista a derrubar a Monarquia pela via do golpe militar. Em suma, o Partido Republicano tornara-se classista como eram os partidos monárquicos, com o agravante de que, tendo atrás de si a grande propriedade rural escravis- 
ta, ele passara a ter por combustível o ódio da velha oligarquia rural contra a Monarquia abolicionista (Nabuco, 1999, p. 62). O exame do pessoal de que o partido republicano era composto confirmava aos olhos de Nabuco, portanto, o risco embutido na mudança de regime: no quadro da frágil sociedade brasileira, a aparentemente atrasada Monarquia representava a possibilidade de progresso verdadeiro, ao passo que a aparentemente mais moderna República implicaria, ao revés, o retrocesso que poria em risco todas as conquistas que o Brasil conseguira forjar até então em matéria de desenvolvimento político. Antes de constituído politicamente o povo, ou seja, de estruturada a sociedade, a República só viria legitimar a opressão oligárquica que com muito mais violência sobre ele recairia: "Ainda não temos povo, e as oligarquias republicanas, em toda a América, têm mostrado ser um terrível impedimento à aparição política e social do povo" (Nabuco, 1949d, p. 373). Daí que Nabuco preferisse "conservar a nossa tradição monárquica a tentar com a unidade nacional uma experiência sociológica" (Nabuco, 1989, p. 60).

\section{A Monarquia democrática}

Possuindo na cúpula do Estado uma autoridade independente e apartidária, o desenho institucional da monarquia favorecia a futura de democratização do país. Embora reconhecesse que o privilégio dinástico atentava contra a democracia em tese, Nabuco argumentava que, haja vista que o povo brasileiro estava submetido a um feudalismo agrário - um privilégio oligárquico -, o privilégio dinástico, pairando sobre a oligarquia, se convertia num agente de nivelamento social, isto é, de democratização, tal qual no absolutismo europeu. Para passar da Monarquia popular para a democracia pura, ou seja, para a República, seria preciso aguardar que a Monarquia concluísse a obra de reparação que lhe incumbia para em seguida abolir, sem risco, o tão 
recriminado privilégio dinástico (Nabuco, 1989, p. 395). Era no interesse mesmo do princípio da igualdade democrática, pois, que se deveria preservar a Monarquia para dobrar o poder oligárquico que avassalava o país. E, referindo-se à Abolição, Nabuco anotava irônico: "O privilégio político de repente devorou, como a baleia devora sardinha, todos esses enxames de privilégios de senhor. Está aí um fato de seleção natural importante, uma grande utilidade pública, o privilégio servindo de instrumento da igualdade, exatamente como a força tem servido de iniciador do direito" (Nabuco, 1989, pp. 392-393). Por essas razões, ele também via no Império um instrumento para atingir fins democráticos: ele era "a arma com que se pode conquistar a emancipação do povo"; "a alavanca de que o liberalismo precisa para altear o proletariado nacional” (Nabuco, 1989, pp. 381, 384).

$300 \quad$ Se a república fosse uma tutela capaz de proteger o povo contra o regime feudal, a monarquia poderia talvez pensar em fazer-se substituir por ela; mas infelizmente a república principia por negar que haja semelhante regime feudal. Não é a sorte do proletariado que a incomoda, é a das classes exploradoras, e quanto ao republicanismo puro, este precisa também da proteção que somente a monarquia lhe pode dar enquanto ele cresce. Ninguém mais do que eu reconhece o que há de patriótico e levado na concepção republicana de Estado, mas não me posso iludir no caso presente: o atual movimento republicano é um puro efeito de causas acumuladas que nada têm de republicanas; é uma contrarrevolução social; é a tentativa de restauração do escravismo pela servidão da gleba; é o despeito de uma classe, explorado e incensado, ao ponto de ameaçar a unidade moral e a integridade material da pátria (Nabuco, 1989, pp. 383-384). 


\section{A monarquia republicana}

Em primeiro lugar, a dissociação entre regime de governo republicano e "o sentimento de res publica" (Jornal do Brasil, 1891a) permitia-lhe acusar a confusão em que incorriam os adversários da monarquia ao suporem que "o ideal republicano se realiza melhor sob a forma republicana da América do que sob a forma monárquica da Inglaterra" (Nabuco, 1989, p. 380). A experiência demonstrara que entre as duas formas de governo havia "espaço para os piores despotismos" e que, sem democracia, a República não passava de "um verdadeiro estelionato" (Nabuco, 1901, p. 63). Por isso, Nabuco se dava ao luxo de dizer-se republicano na Suíça, nos Estados Unidos e no Chile, onde a república era a tradição nacional ou a "forma psicológica" do país, e monarquista, onde ela servisse de ambiente à liberdade para que ela pudesse crescer e frutificar, como na Inglaterra, em Portugal, na Espanha e na Bélgica (Nabuco, 1989, p. 380). Uma vez que, segundo o seu idealismo prático, toda a ação política deveria ser precedida de um exame sociológico sobre o terreno sobre o qual pretendesse incidir, o critério decisivo no deslindamento da questão do regime de governo mais adequado ao Brasil passava forçosamente pela consideração de suas necessidades e circunstâncias específicas. Uma vez que o país estava habituado a um regime monárquico lograra preservar a ordem liberal num ambiente naturalmente hostil, a Nabuco não parecia provável que o ideal republicano se favorecesse da ruptura com a tradição histórica acumulada. Ao contrário, dever-se-ia envidar esforços para que o civismo se expandisse sobre as mesmas bases, que haviam se revelado seguras. A transformação radical das instituições, substituindo a plataforma por que a ordem e o Estado de direito haviam sido erigidos, embutia o risco de desencadear uma série de efeitos regressivos, similares àqueles surtidos nos demais países do continente. 
Todo o mundo sabe o que tem sido a vida de muitos desses Estados e ao que foram eles reduzidos pela ambição do mando supremo. Que resultado chegaram a proclamar os homens mais importantes de quase todas as repúblicas, os seus mais sinceros e verdadeiros patriotas? A ditadura, somente a ditadura (Nabuco, 1989, p. 389).

Nem por isso Nabuco deixava-se enredar por uma visão idílica da vida pública do Império; ele reconhecia que ela não havia sido farta em episódios reveladores do clientelismo, do privatismo e outros vícios na atividade política. Ocorre que, consideradas em si mesmas, corrupção e civismo tinham causas mais sociais do que políticas; eram os males da nossa má-formação que levavam os líderes a desconhecerem que "o governo é uma função do estado e não do indivíduo”. No entanto, conforme implícito naquele raciocínio, Nabuco acreditava que a engenharia institucional pudesse 302 contribuir para incentivar ou coibir a corrupção. Se a própria sociedade demonstrava "a mais absoluta indiferença" acerca dela, devido à "relaxação do nosso senso moral, junto à bondade da nossa índole”, ele concluía que somente uma força estranha ao meio, comprometida com os valores republicanos, poderia moralizá-lo: "O nosso Cromwell tinha que nos cair do céu, e enquanto levasse a corrupção a ferro e fogo, havia de ficar no ar" (Nabuco, 1989, p. 397). Segundo Nabuco, a influência mais republicana da política brasileira havia sido o próprio Imperador, censurando os ministros nos seus excessos facciosos, sublinhando a importância de uma conduta ilibada, esforçando-se pela moralidade eleitoral e alternando os partidos no poder, sempre pessoalmente desinteressado. Por que duvidar, portanto, que a Monarquia pudesse continuar a "reformar os costumes e criar na sociedade o senso moral que lhe falta"? (Nabuco, 1989, p. 399). Por outro lado, na medida em que poria a chefia do Estado ao alcance de qualquer um, lhe 
parecia que, no Brasil, o advento da República provocaria o efeito oposto, potencializando as ambições e os interesses predatórios de uma sociedade que ignorava o sentido cívico da vida pública. "A república representaria a maior relaxação, exatamente porque seria a sociedade tal qual é, sem o único ponto de apoio possível para essa reação da moralidade" (Nabuco, 1989, p. 398). Desaparecendo a tutela da Monarquia sobre o sistema político e a sociedade informe que jazia debaixo dele, desapareceria a única fonte que ainda poderia irrigá-la, do alto, com o exemplo do desinteresse e da abnegação - ou seja, com valores republicanos. Eis por que, para o repúblico Nabuco, "o erro fundamental dos republicanos" estava em supor que "a monarquia era um movimento ou fase contrária à aspiração republicana, quando a monarquia era o núcleo em que essa aspiração começava a consolidar-se" (Jornal do Brasil, 1891b).

\section{A monarquia liberal}

Outra desvantagem do regime republicano em países de carentes de sentimento cívico e liberal estava na falta de uma autoridade imparcial na cúpula do Estado, que, como poder moderador, tivesse por missão preservar o governo constitucional. Nabuco nada tinha a opor à eletividade da chefia do Estado em países cujas sociedades houvessem alcançado um grau de estruturação que lhes facultasse resistir à corrupção, à tirania e à oligarquia. Porém, entre países ainda faltos de "perfeita educação política", lhe parecia que aquela eletividade produzia efeitos extremamente negativos. Nesse ponto, a impossibilidade de neutralizar o poder do chefe de Estado lhe parecia um dos principais obstáculos à estabilização da ordem política e posterior desenvolvimento das repúblicas na América Latina. Ao invés de agirem como magistrados, os presidentes latino-americanos empregavam a máquina pública em benefício das facções a que pertenciam, recorrendo às fraudes e à violência para 
nela se perpetuarem. Ao impedirem a alternância partidária, eles liquidavam o sistema representativo; ao privarem o país de uma autoridade arbitral, obrigando a oposição a recorrer à guerra civil para forçar a alternância do poder, eles comprometiam a ordem pública que deveriam preservar. Assim "barbarizadas", essas pobres nações só faziam recuar mais e mais de seu ideal político civilizatório, recaindo na anarquia, na oligarquia, na tirania (Nabuco, 1989, p. 395). Essas situações não ocorriam nas Monarquias parlamentares, cujos chefes apartidários asseguravam, enquanto magistrados, a impessoalidade do poder e a alternância dos partidos no poder - e, com elas, o governo constitucional representativo.

\section{$* * *$}

Ainda que sucinta e incompleta, a exposição sistemati304 zada do pensamento político produzido por Nabuco depois da Abolição acima esboçada basta para apontar o equívoco das interpretações classistas ou psicologistas que dele desdenham como reacionário, conservador, saudosista, autoritário ou aristocrático (conceitos estes que espero, noutra ocasião, poder discutir com mais vagar). Ao invés de condenada de forma sumária por seu "caráter aristocrático", a sofisticada reflexão de Nabuco se destaca, entre outros aspectos, como valiosa contribuição à teoria das sequências e condições históricas de advento da democracia. O autor de Balmaceda está em boa companhia: é Robert Dahl quem afirma (quase um século depois...) que o advento de uma poliarquia estável é mais provável naqueles países em que a competição política restrita a uma elite de valores homogêneos precede o processo de expansão da participação política:

Tolerância e segurança mútua têm mais chances de se desenvolver no âmbito de uma pequena elite que 
compartilhe perspectivas semelhantes do que em meio a um largo e heterogêneo conjunto de líderes representando estratos sociais de objetivos, interesses e pontos de vista radicalmente díspares (Dahl, 1971, p. 37).

Além disso, já ficou claro que seu monarquismo não decorria de sua oposição à democracia ou à república, mas da razão oposta - porque ele se julgava um verdadeiro repúblico, comprometido até os cabelos com os ideais cívicos de liberdade e igualdade -, somada a um diagnóstico sociológico da sociedade brasileira. Nabuco não via nada de verdadeiramente republicano no movimento homônimo, cuja vocação privatista, autoritária e oligárquica crescia na medida em que ele se aliava ao latifúndio escravista e ao militarismo positivista, potencializando, com o seu êxito, os valores antirrepublicanos, antiliberais e antidemocráticos já presentes na sociedade. No nosso estádio inicial de formação nacional, a Monarquia lhe parecia o meio por que se poderia passar com segurança à República, fomentando o civismo, o liberalismo e, portanto, preparando o povo para a democracia. O caráter instrumental de sua defesa da Monarquia é patente: ele não a defende como intrinsecamente superior à República como forma de governo, mas como forma possível da República no Brasil - espécie de estufa dentro da qual poderia medrar a planta da liberdade e do civismo no terreno adverso da América Latina. Daí que ele intitulasse um de seus artigos em O Comércio de São Paulo, em 1896, com o slogan "a monarquia é que era a república".

Tal ponto me parece de particular relevância na medida em que permite ver que o foco de sua análise no período não era a da monarquia em si mesma, mas de uma determinada institucionalidade que, para aclimatar a liberdade, a democracia e a República, precisava ser descolada da atrasada sociedade brasileira, podendo ser eventualmente abandonada depois desse processo. Trata-se de pensar uma 
arquitetura institucional presidida por um núcleo social comprometido com a ética republicana, tornada autônoma em relação à sociedade real, tida por corrupta, autoritária e oligárquica, capaz de, enquanto tal, assegurar o Estado de direito e, por meio de uma pedagogia cívica, preparar o terreno para a democracia. De fato, ao longo da atividade intelectual desenvolvida durante a década de 1890, Nabuco dedicou-se de modo insistente, embora discreto, a pensar como seria possível reorganizar o regime republicano à luz da experiência monárquica. Não me refiro apenas à sua tentativa de, num exercício de "política retrospectiva", fazer de Um estadista do império um espelho de príncipe para os futuros chefes de Estado brasileiros (Mello, 1997; Salles, 2002). Refiro-me à sua obsessão com a ideia de restauração do Poder Moderador no interior da República, como garantidor do Estado de direito - desde reivindicar um mecanismo como aquele para todos os países da América Latina, como 306 remédio à doença crônica da intolerância política (Nabuco, 1949), até recomendar aos presidentes eleitos da República, como Afonso Pena, que fossem "os continuadores do Imperador" na chefia do Estado (Nabuco, 2005, p. 360). Um manuscrito arquivado na Fundação Joaquim Nabuco exprime à perfeição essa tentativa de repensar a organização republicana à luz da experiência imperial:

Se eu acreditasse em república no Brasil, eis mais ou menos como a julgaria viável: um Tribunal de Justiça composto pela primeira ilustração do país, com poderes discricionários para fazer cumprir a Constituição; um Conselho de Estado composto da primeira ilustração e prudência, como assessor do Executivo; um Presidente por dez anos e reelegível, com ministros responsáveis; um exército pequeno, que fosse a verdadeira nobreza do país, educado por oficiais estrangeiros; um tribunal de contas, com respeito a emissões, despesas etc.; uma lei perfeita de autonomia 
municipal ou de divisão departamental que substituísse a federação dos Estados, e para presidente dessa república um príncipe de sangue ou um general vitorioso, e a capital em uma ilha. Tudo isso lhe parece absurdo. Pois é a solução mais aproximada que eu posso achar para a quadratura republicana ${ }^{7}$.

A mudança de enfoque aqui proposta no exame da obra produzida por Nabuco na década de 1890, que busque levá-lo ao sério, sugere toda uma agenda de pesquisa, da qual gostaria de explicitar algumas delas, a título de ilustrar a sua fecundidade. Em primeiro lugar, do ponto de vista historiográfico, há toda uma literatura que tem crescentemente confirmado o diagnóstico de Nabuco a respeito do novo regime, dada a sua baixíssima densidade republicana, liberal e democrática. Contento-me em lembrar aqui $O s$ bestializados, de José Murilo de Carvalho, e o Memorial das desigualdades, de Maria Emília Prado. Do ponto de vista ideológico, creio que uma comparação cuidadosa da obra de Nabuco com a de republicanos seus contemporâneos, como Campos Sales de Cartas da Europa, o Alcindo Guanabara dos Discursos parlamentares e o Felisbelo Freire de História constitucional da república, daria ao leitor uma impressão inversa àquela que sugere o rótulo de aristocrata conservador: a de que os conservadores eram os republicanos, aferrados ao princípio da autoridade, sancionando todas as atrocidades cometidas pela ditadura militar, e que o Nabuco de Balmace$d a$ era um liberal que vibrava na mesma sintonia do Rui Barbosa de Cartas de Inglaterra - que era então o nec plus ultra do liberalismo republicano brasileiro. Além disso, a recuperação do pensamento nabuqueano do período abre caminhos adicionais para a interpretação do pensamento políti-

7 Arquivos da Fundação Joaquim Nabuco. Anotações manuscritas de Joaquim Nabuco sobre a política (JNMp2cap1doc26a7g3). 
co e social brasileiro. Ao longo desta exposição, o estudioso desse campo do conhecimento já deve ter se dado conta do quanto a proposta de Nabuco de um republicanismo pelo alto se assemelha daquela efetuadas antes dele por José Bonifácio, Caravelas e Uruguai, e depois dele por Alberto Torres, Oliveira Viana e Guerreiro Ramos. Um estudo cuidadoso do impacto da obra nabuqueana durante a década de 1910 provavelmente haveria de revelar ser Nabuco o elo perdido da linhagem saquarema dos nossos pensadores políticos. Seria possível então juntar as duas pontas da sua reflexão, a social e a política, a abolicionista democrática e a institucionalista liberal, debaixo de um mesmo eixo analítico, que poderia iluminar certas questões do nosso pensamento político e social que ainda jazem na penumbra.

Em quarto lugar, chamo a atenção para o fato de que o conceito de República entendido como "bem comum" ou "coisa pública” foi recentemente resgatado, encontrando-se 308 no cerne de alguns dos mais importantes debates da teoria política atual. Ao escrever um livro no começo da década cujo tema era justamente a república, Renato Janine Ribeiro descreve-a nos precisos termos postos por Nabuco: trata-se de um sentimento cívico antes que um regime de governo; afirma que o seu adversário mortal não é a Monarquia, mas a corrupção e o patrimonialismo; e sugere que o país onde o ideal republicano parece mais perfeitamente realizado é a Inglaterra, regida por uma monarquia parlamentarista em que a coisa pública é simbolizada por um chefe de Estado apartidário e imparcial (Ribeiro, 2001). Também recentemente, uma das mais conhecidas revistas do país, estampou uma foto de D. Pedro II na capa de uma edição, vestindo a faixa presidencial, apontando-o como modelo de virtude republicana a ser seguido pelos atuais chefes de Estado (Gryzinsky, 2007). Por fim, do ponto de vista político-constitucional, por sua vez, a obsessão de Nabuco em torno de um mecanismo qualquer que garantisse o prima- 
do do pluralismo na América Latina, demonstra a sua sensibilidade para um tema que teria largo desenvolvimento no século XX: aquele da preservação dos direitos humanos contra no plano nacional e internacional contra o arbítrio dos regimes autoritários ${ }^{8}$. Esta era uma preocupação também de Rui Barbosa, o outro liberal democrata do período. A disseminação de mecanismos de controle jurisdicional da constitucionalidade por quase todos os países do mundo, na forma de Cortes Constitucionais, bem como as intervenções humanitárias e a instalação do Tribunal Penal Internacional, julgando os ditadores decaídos por crimes de genocídio, seriam certamente saudadas por Nabuco como conquistas da civilização, que respondiam às suas angústias e preocupações. A literatura jurídica a respeito do tema é imensa e chega com força na teoria política: basta lembrar que Pierre Rosanvallon, um dos maiores teóricos contemporâneos da democracia, lhe dedicou um capítulo inteiro de seu último livro (Rosanvallon, 2008).

Tais são fatos que, independentemente dos valores, motivos e intenções que lhe são subjacentes, sugerem a atualidade e a produtividade do pensamento republicano do "segundo Nabuco". Daí a necessidade de lhe conferir maior atenção, devolvendo-lhe a integridade de sua dimensão intelectual e redimensionando-o como pensador da nossa condição nacional.

\section{Christian Edward Cyril Lynch}

é professor do Programa de Pós-Graduação em Direito da UGF e do Programa de Pós-Graduação em Ciência Política do Iesp-Uerj.

\footnotetext{
8 Ainda em 1904, por exemplo, escreve Nabuco em seu diário ter o desejo de "um dia escrever um pequeno tratado sobre o direito que a civilização tem de intervir em Estados que perderam a característica de nações organizadas e se tornaram praticamente hordas de bandidos organizados, exercendo a espoliação, o terror, a desmoralização da comunhão indefesa" (Nabuco, 2005, p. 294).
} 


\section{Referências bibliográficas}

ALENCAR, J. A. 2008. "Joaquim Nabuco: monarquista no Brasil, republicano no Chile”. In: NABUCO, J. Balmaceda. São Paulo: Cosac Naify.

ALONSO, A. 2002. Ideias em movimento: a geração de 1870 na crise do Brasil-império. São Paulo: Paz e Terra.

2007. Joaquim Nabuco: os salões e as ruas. São Paulo: Companhia das Letras.

2009a. "Arrivistas e decadentes: o debate político intelectual brasileiro na primeira década republicana”. Novos Estudos, no 85, pp. 131-148. 2009b. "A década monarquista de Joaquim Nabuco". Revista USP, no 83 , pp. 53-66.

CANDIDO, A. 2004. "Radicalismos". In: Vários escritos. Rio de Janeiro: Duas Cidades.

CARVALHO, M. A. R. 2000. Joaquim Nabuco e a política. Tempo Brasileiro, no 140 , pp. 7-33.

CARVALHO, J. M. 1987. Os bestializados: o Rio de Janeiro e a República que não foi. São Paulo: Companhia das Letras.

DAHL, R. A. Poliarchy: participation and oposition. New Haven/Londres: Yale University Press.

FERNANDES, M. L. 2007. "Silva Jardim e Joaquim Nabuco: uma polêmica acerca da Abolição e da República”. Paper apresentado no XIII Congresso Brasileiro de Sociologia, Recife (mimeo.).

FURET, F. 1989. Pensando a revolução francesa. Rio de Janeiro: Paz e Terra.

GRYZINSKY, V. 2007. "O rei e nós”. Veja, 14 nov. 2007.

JORNAL DO BRASIL. 1891a. "Outras ilusões republicanas: as raízes da monarquia”.

1891b. "Outras ilusões republicanas (II): as raízes da monarquia”, 4 out.

LYNCH, C. E. C. 2008. "O pensamento conservador ibero-americano na era das independências (1808-1850)". Lua Nova, no 74, pp. 59-92.

MELLO, E. C. 2001. A ferida de Narciso: estudos de história regional. São Paulo, Ed. Senac.

MILL, J. S. 1983. O governo representativo. São Paulo: Ibrasa.

MITCHELL, L. 2005. The whig world (1760-1837). Londres, Hambledon Continuum.

NABUCO, J. 1901. Escritos e discursos literários. Rio de Janeiro: Garnier. 1937. Pensamentos soltos. Rio de Janeiro/São Paulo: Civilização Brasileira/Companhia Editora Nacional. 1949a. Balmaceda. São Paulo: Progresso Editorial. 1949b. Minha formação. Rio de Janeiro: W. M. Jackson Inc. Editores. 
1949c. Cartas aos amigos. São Paulo: Instituto Progresso, (vol. 2). 1949d. Discursos parlamentares. São Paulo: Instituto Progresso. 1989. "Artigos de Joaquim Nabuco (última fase) no jornal $O$ País (seção 'Campos Neutro')”. In: GOUVÊA, F. C. (org.). Joaquim Nabuco entre a Monarquia e a República. Recife: Fundação Joaquim Nabuco; Massangana.

1997. Um estadista do império. Rio de Janeiro: Top Books. 1999. A abolição e a república. Recife: Ed. UFPE. 2005. Diários: 1873-1910. Rio de Janeiro/Recife: Bem-Te-Vi/Fundação Joaquim Nabuco.

NOGUEIRA, M. A. 1984. As desventuras do liberalismo: Joaquim Nabuco, a monarquia e a república. Rio de Janeiro: Paz e Terra.

2000. "Das tensões, dialéticas e antinomias: o encontro de Nabuco com a política”. Tempo Brasileiro, no 140, pp. 75-96.

PRADO, M. E. 2005. Memorial das desigualdades: os impasses da cidadania no Brasil (1870-1902). Rio de Janeiro: Revan.

RIBEIRO, R. J. 2001. A república. São Paulo: Publifolha.

ROSANVALLON, P. 2008. La legitimite démocratique: impartialité, reflexivité, proximité. Paris: Seuil.

SALLES, R. 1997. Nostalgia imperial: a formação da identidade nacional do Brasil do Segundo Reinado. Rio de Janeiro: Topbooks. 2000. "Joaquim Nabuco e a frustração da nação abolicionista". Tempo Brasileiro, no 140, pp. 31-54. 2002. Joaquim Nabuco: um pensador do império. Rio de Janeiro: Topbooks.

STERNHELL, Z. 1997. La droite revolutionnaire - 1885-1914: les origines françaises du fascisme. Paris: Gallimard.

TOCQUEVILlE, A. 2001. A democracia na América: leis e costumes. São Paulo: Martins Fontes.

VIANA FILHO, L. 1952. A vida de Joaquim Nabuco. São Paulo: Companhia Editora Nacional. 


\section{O IMPÉRIO É QUE ERA A REPÚBLICA: A MONARQUIA REPUBLICANA DE JOAQUIM NABUCO}

\section{CHRISTIAN EDWARD CYRIL LYNCH}

Resumo: $\mathrm{O}$ artigo debruça-se sobre a incompreendida fidelidade à Monarquia por parte de Joaquim Nabuco depois da Abolição da Escravatura, quando ele passou a refletir sobre as condições de possibilidade de construção de uma sociedade republicana liberal no Brasil. Estudando seus escritos monarquistas publicados entre 1888 e 1896, percebe-se que Nabuco permaneceu monarquista por julgar que o advento do regime republicano, na modalidade oligárquica proposta pelo partido homônimo, ao invés de auxiliá-la, prejudicaria o advento de uma sociedade autenticamente republicana, liberal e democrática. Considerações de ordem pragmática levavam-no a ver a Monarquia como um instrumento capaz de mais bem preparar a sociedade brasileira para uma República que fosse além do mero rótulo, sem desnível entre forma e conteúdo, o país legal e o real.

Palavras-chave: Pensamento político brasileiro; Joaquim Nabuco; Império; República; Monarquismo. 


\section{THE BRAZILIAN EMPIRE AS THE TRUE REPUBLIC: JOAQUIM NABUCO'S PROJECT OF A REPUBLICAN MONARCHY}

Abstract: The article focuses on the misunderstood loyalty to the monarchy by Nabuco after the Abolition of Slavery, when he began to reflect on the conditions of possibility of building a liberal republican society in Brazil. In studying his writings published between 1888 and monarchists 1896, it is clear that Nabuco remained royalist judge by the advent of the republican regime, in the form proposed by the oligarchic party namesake, instead of help it would impair the advent of a truly republican society, liberal and democratic. Pragmatic considerations led him to see the monarchy as a tool to better prepare the Brazilian society to a republic that would go beyond the mere label, with no gap between form and content, the legal and real country.

Keywords: Brazilian political tought; Joaquim Nabuco; Empire; Republic; Royalism.

Recebido: 01/06/2011 Aprovado: 16/12/2011 